\title{
Konsep Kepemilikan Hak Atas Merek di Indonesia (Studi Pergeseran Sistem “Deklaratif” ke dalam Sistem "Konstitutif”)
}

\author{
R. Murjiyanto \\ Fakultas Hukum Universitas Janabadra \\ Jln. Timoho II/ 40 Yogyakarta \\ rmurjiya@yahoo.com
}

Naskah diterima: 22/10/2016; revisi: 25/11/2016; disetujui: 22/12/2016

\begin{abstract}
This research is designed to study a number of issues including first, what becoming the philosophical base of consideration in the displacement in the brand registration from the declarative system (first to Use) into the system. Constitutive (First to File)? Second, Why the occurrence of equal brand between one and other parties still exist? Third how does the model of implementation of Constitutive System in the brand registry give the just legal security? This research concluded first, the replacement of the declarative system (First to Use) into the Constitutive System (First to File) in the management of brand in Indonesia is based upon the consideration to reach the legal objective particularly for guaranteeing the legal security and justice in the right protection for the brand owner. Second, the occurrence of registration of equal brand, even the one with good reputation, commonly is based upon a bad intention of the registrants prioritizing their own interest for profit by using the fame. Third, the implementation of Constitutive System or "First to File" in brand registration to give a just legal security that is by applying the constitutive system or "First to File" tightly and consistently in which the rights and protection to the brand are only given the registered brand owner and any claim of cancelation can only be done by the registered brand owner.
\end{abstract}

Keywords: Replacement; system; constitutive; brand rights

Abstrak

Penelitian ini mengkaji permasalahan, pertama, apa yang menjadi landasan filosofis pertimbangan pergeseran dalam pendaftaran merek dari sistem deklaratif (first to Use) ke dalam Sistem Konstitutif (First to File)? Kedua, mengapa dengan berlakunya Sistem Konstitutif masih terjadi pendaftaran Merek yang sama milik pihak lain? Ketiga, bagaimanakah model pemberlakuan Sistem Konstitutif dalam pendaftaran Merek agar memberikan kepastian hukum yang adil? Penelitian ini dilakukan dengan menggunakan pendekatan yuridis normatif yang didukung data empiris. Kesimpulan hasil penelitian ini pertama, pergeseran Sistem Deklaratif ke dalam Sistem Konstitutif dalam pendaftaran Merek, untuk menjamin kepastian hukum yang adil. Kedua, terjadinya pendaftaran Merek yang sama oleh pihak lain, pada umumnya dilandasi adanya itikad tidak baik. Ketiga, model pengaturan pendaftaran Merek untuk memberikan kepastian hukum yang adil yaitu dengan model pemberlakukan sistem konstitutif secara ketat dan konsisten.

Kata-kata Kunci : Pergeseran; sistem; konstitutif; merek 


\section{Pendahuluan}

Masalah Merek di Indonesia pertama kali diatur dalam Undang-Undang Nomor 21 Tahun 1961 tentang Merek Perusahaan dan Merek Perniagaan yang diundangkan pada 11 Oktober 1961, selanjutnya dapat disebut UU Merek 1961, menggantikan peraturan warisan kolonial Belanda Tahun 1912 tentang Hak Milik Perindustrian, yaitu Reglement Industriale Eigendom Kolonien 1912, S 1912 No. 545 jo. 1913-214 yang dianggap sudah tidak sesuai lagi. Berdasarkan Undang-Undang Nomor 21 Tahun 1961, bagi pemilik Merek agar dapat dilindungi haknya tidak ada keharusan untuk mendaftarkan. Sebagai dasar hak atas Merek ditentukan atas dasar pemakaian pertama kali, sedangkan pihak yang mendaftar hanya menimbulkan anggapan, bahwa ia sebagai pemakai pertama kali, sepanjang tidak ada bukti sebaliknya. ${ }^{1}$ Sistem ini dikenal dengan Sistem Deklaratif atau sistem "first to use". Terhadap pemilik Merek terdaftar dapat diajukan pembatalan oleh pihak yang menganggap sebagai pemakai pertama kali sekalipun tidak terdaftar. ${ }^{2}$

Pendaftaran dengan sistem Deklaratif ini dalam kenyataannya banyak terjadi sengketa Merek, karena sistem ini sangat potensial terjadi pembajakan terhadap Merek-merek yang mempunyai reputasi tinggi atau Merek yang sudah terkenal. Di samping itu, telah cukup banyak praktisi dan pengamat hukum Merek berpendapat bahwa Undang-Undang Merek 1961 memiliki banyak kelemahan karena dengan Sistem Pendaftaran Deklaratif atau "first to use principle" kerapkali menimbulkan kesulitan dalam menentukan siapa sebenarnya pemakai pertama (yang beritikad baik) terhadap Merek yang dipermasalahkan. ${ }^{3}$ Dengan demikian dalam sistem deklaratif

\footnotetext{
${ }^{1}$ Endang Purwaningsih, Perkembangan Hukum Intellectual Property Rights Kajian Hukum Terbadap Hak atas Kekayaan Intelektual dan Kajian Komparatif Hukum Paten, Ghalia Indonesia, Bogor, 2005 hlm. 11, bahwa dalam pendaftaran Merek dikenal dua sistem pendaftaran, yakni Sistem Deklaratif dan Sistem Konstitutif. Sistem Deklaratif yang biasa juga disebut sistem pasif, memberikan asumsi bahwa pihak yang Mereknya terdaftar adalah pihak yang berhak atas Merek terdaftar tersebut sebagai pemakai pertama. Lihat juga H. OK Saidin, Aspek Hukum Hak Kekayaan Intelektual (Intellectual Property Rights), PT Raja Grafindo Persada, Jakarta, 2003, hlm. 367, bahwa Status pendaftaran hanyalah merupakan status anggapan bahwa Mereka yang telah mendaftarkan Mereknya adalah yang memakai pertama tersebut sehingga se-waktu-waktu Merek yang telah didaftarkan oleh seseorang dapat saja diganggu gugat oleh orang yang merasa lebih berhak atas Merek tersebut.

${ }^{2}$ Hartono Projomardojo, "UU Merek 1961 dan Permasalahan-nya Dewasa Ini”, disampaikan di Ceramah Seminar Hukum Atas Merek, Badan Pembinaan Hukum Nasional, Bina Cipta, Jakarta, 1978, hlm. 21, bahwa dengan dianutnya stelsel declaratoir, maka jika Merek yang didaftar itu pada keseluruhannya atau pada pokoknya sama dengan Merek orang lain yang telah memakai Merek itu lebih dulu dari orang yang terdaftar Mereknya itu, maka orang yang telah memakai lebih dahulu Merek tersebut dapat mengajukan permohonan agar supaya pendaftaran Mereknya dibatalkan. Juga sesuai dengan Pasal 10 UU No. 21 Tahun 1961 tentang Merek.

${ }^{3}$ Yoshiro Sumida danInsan Budi Maulana, Perlindungan Bisnis Merek Indonesia-Jepang, Pustaka Sinar Harapan, Jakarta, 1994, hlm. 20.
} 
ini apabila terjadi sengketa tidak mudah pembuktiannya tentang siapa sebenarnya yang pertama kali memakai Merek guna menentukan siapa yang benar-benar berhak. Seorang pemilik Merek yang tidak mendaftarkan mereknya, harus menyediakan bukti-bukti tentang pemakaian mereknya dengan berbagai surat-surat atau kesaksian lain yang tidak mudah untuk dikumpulkan atau disajikan. ${ }^{4}$

Sehubungan hal tersebut maka diundangkan Undang-Undang Nomor 19 Tahun 1992 tentang Merek, selanjutnya disebut UU Merek 1992, yang menerapkan Sistem Pendaftaran Konstitutif (first to file) sebagai pengganti UU Merek Tahun 1961 yang menerapkan sistem pendaftaran deklaratif (Firs to Use). Kemudian Undang-Undang Nomor 19 Tahun 1992 ini juga telah dirubah dengan UndangUndang Nomor 14 Tahun 1997 tentang Perubahan Undang-Undang Nomor 19 Tahun 1992 tentang Merek. Kemudian di rubah dan diganti dengan UndangUndang Nomor 15 Tahun 2001 tentang Merek, selanjutnya disebut UU Merek 2001. Baik dalam UU Merek 1992 dengan perubahannya dengan UU Nomor 14 Tahun 1997 maupun dalam UU Merek 2001 sistem pendaftarannya sama, dengan menganut Sistem Konstitutif (First to File) yaitu adanya kewajiban pendaftaran bagi pemilik Merek yang ingin memperoleh perlindungan hukum menurut UU Merek.

Dengan sistem pendaftaran sebagai dasar pemberian hak, maka perlindungan hak berlaku bagi pemilik Merek terdaftar. Namun sejak berlakunya Undang-Undang Merek 1992 dengan perubahannya 1997 sampai dengan berlakunya Undang-Undang Merek 2001 masih memberi perlindungan secara khusus terhadap Merek tidak terdaftar, dengan menolak pendaftaran Merek yang sama dengan Merek terkenal. Pemilik Merek tidak terdaftar juga dapat mengajukan pembatalan Merek, bahkan tanpa syarat terkenal.

\section{Rumusan Masalah}

Permasalahan yang berhubungan dengan pergeseran sistem pendaftaran Deklaratif menjadi Konstitutif dalam pendaftaran Merek, sebagai berikut, pertama, apa yang menjadi landasan filosofis pertimbangan pergeseran dalam pendaftaran Merek dari Sistem Deklaratif (first to Use) ke dalam Sistem Konstitutif (First to File) ? Kedua, mengapa dengan berlakunya Sistem Konstitutif masih terjadi pendaftaran 
Merek yang sama milik pihak lain bahkan mempunyai reputasi terkenal yang akhirnya menimbulkan sengketa pembatalan? Ketiga, bagaimanakah model pemberlakuan Sistem Konstitutif dalam pendaftaran Merek agar memberikan kepastian hukum yang adil?

\section{Tujuan Penelitian}

Penelitian ini bertujuan untuk mengkaji dan menganalisis, pertama, landasan filosofis dari pergeseran dalam pendaftaran Merek dari sistem Deklaratif menjadi Konstitutif. Kedua, faktor penyebab terjadinya pendaftaran Merek yang sama bahkan mempunyai reputasi terkenal oleh pihak lain yang akhirnya menimbulkan sengketa pembatalan. Ketiga, merumuskan model pemberlakuan Sistem Konstitutif dalam pendaftaran Merek agar memberikan kepastian hukum yang adil.

\section{Metode Penelitian}

Penelitian ini dilakukan dengan menggunakan pendekatan yuridis normatif (legal research), ${ }^{5}$ atau disebut juga dengan penelitian doktrinal, ${ }^{6}$ yaitu menggunakan atau bersaranakan pada sumber data berupa peraturan perundang-undangan, keputusan-keputusan pengadilan, teori-teori maupun konsep hukum dan pandangan para sarjana hukum, yang hasilnya dianalisis dengan menggunakan cara normatifkualitatif.7 Didukung dengan data empiris, dengan mendasarkan atas suatu sampel yang a-selective. ${ }^{8}$ Data penelitian berasal dari naskah jawaban pertanyaan, wawancara, catatan lapangan, foto, vediotape, dokumen-dokumen lainnya. ${ }^{9}$ Sedangkan penelitian kualitatif menurut Kirk dan Miller, menunjuk pada segi "alamiah", yang dipertentangkan dengan "kuantum" atau "jumlah". Sehingga penelitian kualitatif diartikan sebagai penelitian yang tidak mengadakan perhitungan. ${ }^{10}$

${ }^{5}$ Bambang Waluyo, Penelitian Hukum Dalam Praktek, Sinar Grafika, Jakarta, 1991, hlm. 17, lihat juga Johnny Ibrahim mengatakan bahwa, "Metode Penelitian Hukum Normatif" adalah suatu prosedur peneliti ilmiah untuk menemukan kebenaran berdasarkan logika keilmuan hukum dari sisinormatifnya, Logika keilmuan yang ajeg dalam penelitian hukum normatif dibangun berdasarkandisiplin ilmiah dan cara-cara kerja ilmu hukum normatif, yaitu ilmu hukum yang objeknya hukum itu sendiri. Johnny Ibrahim, Teori \& Metode Penelitian Hukum Normatif, cet. pertama, Bayumedia Publishing, Malang, April 2005, hlm. 47.

${ }^{6}$ Suratman, dan Philips Dillah, Metode Penelitian Hukum, Alfabeta, Bandung, 2012, hlm. 11.

${ }^{7}$ Ibid., hlm. 11.

${ }^{8}$ Vredenbregt, J., Metode dan Teknik Penelitian Masyarakat, PT Gramedia, Jakarta, 1978, hlm. 34

${ }_{9}^{9}$ Lexy j. Moleong, Metodologi Penelitian Kualitatif, PT. Remaja Rosdakarya, Bandung, 1989, hlm. 6

${ }^{10}$ Ibid., hlm. 2 


\section{Hasil Penelitian dan Pembahasan}

\section{Landasan Filosofis Pergeseran Pendaftaran Sistem Deklaratif ke dalam Sistem Konstitutif}

Terjadinya pergeseran Sistem Deklaratif (First to Use) ke dalam Sistem Konstitutif (First to File) di Indonesia yaitu semula dengan berlakunya UndangUndang Nomor 21 Tahun 1961 tentang Merek Perusahaan dan Merek Perniagaan berlaku Sistem Deklaratif (First to Use) yang tidak mengaharuskan adanya pendaftaran Merek dan timbulnya hak Merek didasarkan pada pemakaian pertama kali bukan karena pendaftaran, maka sejak diundangkannya UndangUndang Nomor 19 Tahun 1992 tentang Merek berlaku Sistem Konstitutif (FirsttTo File) yang mengharuskan adanya pendaftaran Merek bagi Mereka yang ingin memperoleh perlindungan hukum, dimana timbulnya hak Merek didasarkan pada pendaftaran.

Adanya perubahan sistem hak Merek tersebut tidak lepas dari pertimbangan bahwa berlakunya Sistem Deklaratif dalam UU Nomor 21 Tahun 1961 dianggap kurang memberikan adanya kepastian dan perlindungan hukum, dengan disertai terjadinya beberapa kasus pembatalan Merek yang justru dimenangkan oleh pihak yang tidak mendaftarkan Mereknya. Dengan sistem yang demikian tentunya akan menyebabkan keengganan bagi pemilik Merek untuk mendaftarkan Mereknya, karena tidak didaftarkanpun, suatu saat didaftarkan oleh pihak lain dapat mengajukan pembatalan, dan hal demikian juga menimbulkan ketidak tertiban administrasi di bidang Merek.

Menurut Sistem Konstitutif (aktif) dengan doktrinnya "prior in filling" bahwa yang berhak atas suatu Merek adalah pihak yang mendaftarkan Mereknya, dikenal pula dengan asas "presumption of ownership". Jadi pendaftaran itu menciptakan suatu hak atas Merek tersebut. Pihak yang mendaftarkan dialah satu-satunya yang berhak atas suatu Merek dan pihak ke tiga harus menghormati hak si pendaftar sebagai hak mutlak. ${ }^{11}$

Adanya perlindungan tersebut menunjukkan bahwa negara berkewajiban dalam menegakkan hukum Merek. Oleh karena itu apabila ada pelanggaran Merek

${ }^{11}$ Muhamad Djumhana dan Djubaedillah, Hak Milik Intelektual, Sejarah, Teori, dan Praktiknya di Indonesia, PT Citra Aditya Bakti, Bandung, 2014, hlm. 256. 
terdaftar, pemilik Merek dapat mengajukan gugatan ke Pengadilan yang berwenang. Dengan perlindungan tersebut maka akan terwujud keadilan yang menjadi tujuan dari hukum. Salah satu tujuan hukum adalah mewujudkan keadilan masyarakat. Dengan perlindungan hukum maka pemilik Merek yang sah terlindungi hak-haknya. ${ }^{12}$

Pertimbangan secara khusus menyangkut perubahan sistem pendaftaran Merek dari Sistem Deklaratif (First to Use) ke dalam Sistem Konstitutif (First to File), disebutkan dalam penjelasan umum UU Merek 1992 bahwa, perubahan dari sistem deklaratif ke sistem konsitutif, karena sistem konstitutif lebih menjamin kepastian hukum dari pada sistem deklaratif. ${ }^{13}$ Sistem deklaratif yang mendasarkan pada perlindungan hukum bagi Mereka yang menggunakan Merek terlebih dahulu, selain kurang menjamin kepastian hukum juga menimbulkan persoalan dan hambatan dalam dunia usaha. Seperti dikatakan bahwa, perlindungan Merek terdaftar mutlak diberikan oleh pemerintah kepada pemegang dan pemakai hak atas Merek untuk menjamin terhadap kepastian berusaha bagi produsen. ${ }^{14}$ Penggunaan Sistem Konstitutif bertujuan menjamin kepastian hukum disertai pula dengan ketentuan-ketentuan yang menjamin segi-segi keadilan. Dalam masa pengumuman permintan pendaftaran Merek dimungkinkan pemilik Merek tidak terdaftar yang telah menggunakan sebagai pemakai pertama untuk mengajukan keberatan. ${ }^{15}$

Penerapan Sistem Konstitutif dalam UU Merek hanya sebatas menimbulkan kewajiaban yang beraspek kepentingan hak keperdataan semata, terutama kepentingan pemilik Merek. Sudah waktunya Indonesia menerapkan Sistem Konstitutif secara ketat dan konsisten dengan menghilangkan ketentuan

\footnotetext{
12 Haryono, "Perlindungan Hukum Terhadap Merk Terdaftar", Jurnal Ilmiah CIVIS, Volume II, No 1, (Januari 2012), hlm. 241.

13 Mohamad Djumhana dan Djubaedillah, Hak Milik Intelektual, Sejarah, Teori, dan Prakteknya di Indonesia, PT Citra Aditya Bakti, Bandung, 2014, hlm. 256.

${ }^{14}$ Hery Firmansyah, Perlindungan Hukum Terbadap Merek, Panduan Memahami Dasar Hukum Penggunaan Dan Perlindungan Merek, Pustaka Yustisia, Yogyakarta, 2011, hlm. 38.

${ }^{15}$ Baca dalam penjelasan umum Undang-Undang Nomor 19 Tahun 1992 tentang Merek. Baca Penjelasan Umum Undang-Undang Nomor 19 Tahun 1992 tentang Merek, pada butir b menjelaskan bahwa perubahan dari Sistem Deklaratif ke sistem konsitutif, karena Sistem Konstitutif lebih menjamin kepastian hukum dari pada Sistem Deklaratif. Sistem Deklaratif yang mendasarkan pada perlindungan hukum bagi Mereka yang menggunakan Merek terlebih dahulu, selain kurang menjamin kepastian hukum juga menimbulkan persoalan dan hambatan dalam dunia usaha. Dalam Undang-undang ini, penggunaan Sistem Konstitutif yang bertujuan menjamin kepastian hukum disertai pula dengan ketentuan-ketentuan yang menjamin segi-segi keadilan.
} 
pengecualian yang masih memberikan perlindungan kepada pemilik Merek yang tidak terdaftar. Di samping itu, penerapan Sistem Konstitutif seharusnya tidak terbatas menimbulkan kewajiban yang bersifat hak keperdataan saja, tetapi juga beraspek kepentingan publik, dengan memberikan sangsi bagi pemilik merek yang sudah menggunakan namun tidak mendaftarkan mereknya.

\section{Perkembangan Penggunaan Sistem Konstitutif dan Masih diberikannya Perlindungan Hukum terhadap Merek Tidak Terdaftar}

Diberlakukannya Sistem Konstitutif dimulai pada saat dikeluarkannya Undang-Undang Nomor 19 Tahun 1992 tentang Merek, yang dalam perkembangannya juga mengalami perubahan. Berkaitan dengan kepentingan reformasi hukum Merek, Indonesia turut serta meratifikasi Perjanjian Internasional Merek WIPO dan WTO yang didalamnya mengandung persetujuan TRIPs, kemudian pada 1997, dalam rangka menyesuaikan dengan perjanjian internasional mengenai aspek-aspek yang terkait dengan perdagangan Hak Kekayaan Intelektual (TRIPs)-WTO, Pemerintah melakukan pembaharuan dengan mengeluarkan UU Nomor 14 Tahun 1997 tentang Perubahan atas Undang-Undang Nomor 19 Tahun 1992 tentang Merek. Terjadi penyesuaian salah satunya terkait dengan perlindungan atas indikasi asal dan geografis dan juga perlindungan Merek terkenal. Dalam perkembangannya dikeluarkan Undang-Undang Nomor 15 Tahun 2001 tentang Merek yang berlaku hingga sekarang. Beberapa perubahan penting yang ada adalah seputar penetapan sementara pengadilan, perubahan dari delik biasa menjadi delik aduan, peran Pengadilan Niaga dalam memutuskan sengketa Merek, kemungkinan menggunakan alternatif dalam memutuskan sengketa dan ketentuan pidana yang diperberat. ${ }^{16}$

Dalam Undang-Undang Merek Tahun 1992 Pasal 3 Hak atas Merek adalah hak khusus yang diberikan Negara kepada pemilik Merek yang terdaftar dalam Daftar Umum Merek untuk jangka waktu tertentu menggunakan sendiri Merek tersebut atau memberi izin kepada seseorang atau beberapa orang secara bersamasama atau badan hukum untuk menggunakannya. Demikian pula dalam undangundang 2001 yang kebetulan diatur dalam pasal yang sama yaitu Pasal 3,

${ }^{16}$ Asian Law Group Pty Ltd, Hak Kekayaan Intelektual Suatu Pengantar, Cet. 5, Alumni, Bandung, 2005, hlm. 132. 
menentukan bahwa Hak atas Merek adalah hak eksklusif yang diberikan oleh negara kepada pemilik Merek yang terdaftar dalam Daftar Umum Merek untuk jangka waktu tertentu dengan menggunakan sendiri Merek tersebut atau memberikan izin kepada pihak lain untuk menggunakannya.

Di samping persamaan tersebut, maka terdapat perbedaan dan perkembangan berlakunya Sistem Konstitutif dalam penentuan hak atas Merek tersebut. Pada saat awal berlakunya Sistem Konstitutif dalam Undang-Undang Nomor 19 Tahun 1992 tentang Merek, ada beberapa poin penting yang berbeda khususnya perlindungan terhadap Merek terkenal sekalipun tidak atau belum terdaftar. Hal ini terlihat adanya ketentuan yang mengharuskan menolak pendaftaran Merek apabila menyerupai Merek yang sudah dimiliki orang lain yang sudah terkenal sekalipun tidak atau belum terdaftar, sebagaimana diatur dalam Pasal 6 ayat (2) Tahun 1992 yaitu, permintaan pendaftaran Merek juga ditotak oleh Kantor Merek apabila: a. merupakan atau menyerupai nama orang terkenal, foto, Merek dan nama badan hukum yang dimiliki orang lain yang sudah terkenal, kecuali atas persetujuan tertulis dari yang berhak.

Ketentuan tersebut menunjukkan masih diberikannya perlindungan hukum bagi Merek terkenal sekalipun tidak terdaftar, ${ }^{17}$ setidaknya undang-undang memerintahkan kepada pejabat pendaftar untuk menolak pendaftaran Merek apabila sama atau menyerupai Merek yang sudah terkenal yang sudah dimiliki oleh pihak lain, yang tentunya maksudnya adalah tidak terdaftar.

Dalam ketentuan pembatalan pendaftaran Merek, juga memberikan peluang bagi pemilik Merek terkenal yang tidak terdaftar untuk mengajukan pembatalan Merek. Hal ini sebagaimana diatur dalam Pasal 56 ayat (3) UU Tahun 1992, yang menyebutkan bahwa, pemilik Merek terkenal yang tidak terdaftar dapat mengajukan gugatan sebagaimana dimaksud dalam ayat (1) setelah mengajukan permintaan pendaftaran Merek kepada Kantor Merek.

Dalam perkembangan selanjutnya dengan diundangkannya UndangUndang Nomor 14 Tahun 1997 tentang Perubahan Undang-Undang Nomor 19

\footnotetext{
17 Baca juga Insan Budi Maulana, "Merek Terkenal Menurut TRIPs Agreement dan Penerapan dalam Sistem Merek Indonesia”, Jurnal Hukum Ius Quia Iustum, Nomor 13 Vol. 7, April 2000, hlm. 121, bahwa di dalam UU Merek juga dicantumkan ketentuan yang memberikan perlindungan terhadap Merek terkenal.
} 
Tahun 1992 tentang Merek, penegasan penentuan hak Merek bahwa hak atas Merek didasarkan atas pendaftaran pada dasarnya adalah sama, karena tidak ada perubahan dengan ketentuan sebelumnya bahwa hak atas Merek didasarkan atas pendaftaran. Sedangkan masih diberikannya perlindungan hukum terhadap Merek yang tidak terdaftar khususnya terhadap Merek terkenal terdapat adanya perubahan, sebagaimana ditentukan dalam Pasal 6 ayat (3), UU Merek 1997 yang menentukan bahwa Kantor Merek dapat menolak permintaan pendaftaran Merek yang mempunyai persamaan pada pokoknya atau keseluruhannya dengan Merek yang sudah terkenal milik orang lain untuk barang dan atau jasa yang sejenis. Penolakan bersifat imperatif, yang menyatakan, Kantor Merek dapat menolak permintaan pendaftaran Merek yang sama atau serupa dengan Merek yang sudah terkenal milik orang lain. Isi pasal ini agak aneh, karena tidak mengharuskan penolakan, kata dapat selayaknya menjadi harus. ${ }^{18}$

Dari ketentuan tersebut menunjukkan bahwa masih diberikannya perlindungan hukum bagi Mereka tidak terdaftar khususnya bagi Merek terkenal, dengan memberi kemungkinan bagi pejabat pendaftar untuk dapat menolak pendaftaran Merek yang mempunyai persamaan pada pokoknya atau keseluruhannya dengan Merek yang sudah terkenal milik orang lain. Perbedaan dan perkembangan dengan ketentuan sebelumnya, yaitu adanya kata dapat. Kata dapat tersebut mengandung makna bukan sebuah keharusan atau kewajiban bagi pejabat pendaftar untuk menolak pendaftaran, sedang dalam ketentuan sebelumnya yaitu UU Merek 1992 penolakan tersebut adalah merupakan sebuah perintah sehingga menjadi keharusan atau kewajiban.

Ketentuan tersebut merupakan perkecualian, karena prinsipnya kewajiban penolakan pendaftaran Merek tersebut hanya apabila sama dengan Merek yang sudah terdafdtar milik pihak lain. Seperti yang di atur dalam Pasal 6 ayat (1) UU Merek 1997, bahwa permintaan pendaftaran Merek harus ditolak oleh Kantor Merek apabila mempunyai persamaan pada pokoknya atau keseluruhannya dengan Merek milik orang lain yang sudah terdaftar lebih dahulu untuk barang dan atau jasa yang sejenis.

\footnotetext{
${ }^{18}$ Ibid., hlm. 125.
} 
Kesulitan dalam menentukan maksud pendaftar untuk mendaftarkan Mereknya apakah dilandasi oleh adanya etikad baik atau tidak sebagaimana disyaratkan dalam undang-undang, bahwa pemohon harus dilandasi oleh etikad baik. Beberapa putusan pengadilan dalam pertimbangan majelis hakim untuk memutus pembatalan Merek umumnya dikaitkan dengan alasan pendaftar dalam mendaftarkan Mereknya dilandasi adanya unsur etikad tidak baik. ${ }^{19}$ Untuk mengetahui apakah pendaftar pada saat mendaftarkan Mereknya beritikad baik atau tidak baik itu tidak mudah, dengan hanya bukti-bukti berupa syarat-syarat pendaftaran secara fisik yang diajukan pendaftar. Sehingga penolakan pendaftaran Merek atas dasar pendaftar tidak beritikad baik sulit dilakukan, akibatnya Merek tetap didaftar sekalipun diajukan oleh pemohon yang beretikad tidak baik, dan akhirnya dikemudian timbul sengketa pembatalan Merek.

Dalam hal kemungkinan mengajukan gugatan pembatalan dalam UU Merek 2001, pemilik Merek yang tidak terdaftar dimungkinkan mengajukan gugatan pembatalan, sebagaimana diatur dalam Pasal 68 ayat (2). Hanya saja berbeda dengan ketentuan sebelumnya yang mensyaratkan Merek yang tidak terdaftar apabila ingin mengajukan gugatan pembatalan ada syarat harus terkenal, sedang dalam UU Merek 2001 pemilik Merek yang tidak terdaftar dapat mengajukan gugatan pembatalan Merek tanpa adanya syarat terkenal.

Dari beberapa contoh kasus dapat diketahui terdapat beberapa kelemahan dari aspek pengaturan dan implementasi Sistem Konstitutif dalam UndangUndang Merek. Dari sisi pengaturan terlihat adanya pemberlakuan Sistem Konstitutif yang tidak tegas dan tidak konsisten, di satu sisi memberlakukan Sistem Konstitutif yang maknanya bahwa pendaftaran merupakan kewajiban timbulnya hak dengan konsekuensi perlindungan diberikan kepada pemilik Merek terdaftar, tetapi di sisi lain masih memberikan perlindungan terlalu luas kepada pemilik Merek yang tidak terdaftar, dengan memperbolehkan pemilik Merek yang tidak terdaftar untuk mengajukan pembatalan tanpa adanya syarat terkenal.

${ }^{19}$ Baca Pasal 4 Undang-Undang Nomor 15 Tahun 2001 tentang Merek, menyebutkan bahwa Merek tidak dapat didaftar atas dasar Permohonan yang diajukan oleh Pemohon yang beriktikad tidak baik. 
Sedangkan dari sisi implementasi dalam beberapa kasus terbukti adanya pengajuan pendaftaran Merek yang secara jelas mengandung persamaan baik sama pada pokoknya bahkan sama pada keseluruhannya tetap dapat diterima pendaftarannya, yang akhirnya terjadi sengketa pembatalan Merek. ${ }^{20}$ Kalau hal ini terjadi terus menerus tentu menimbulkan ketidakpastian bagi dunia usaha terutama bagi perlindungan Merek dan pemberlakuan Sistem Konstitutif kurang bermakna. Disamping itu kurang memberikan kesadaran bagi para pelaku usaha yang menggunakan Merek untuk mendaftarkan Merek yang sebenarnya merupakan suatu kewajiban.

Dari beberapa kasus ternyata juga menggambarkan bahwa faktor penyebab terjadinya pendaftaran Merek milik pihak lain bahkan sudah terkenal dan akhirnya menimbulkan sengketa pembatalan, antara lain dilatarbelakangi oleh a. unsur itikad tidak baik dari pendaftar yang mementingkan diri sendiri dengan mengabaikan kepentingan pihak lain sebagai merek yang sebenarnya. Sedangkan untuk menilai terhadap maksud pendaftar apakah dilandasi adanya itikad baik atau tidak sebagaimana diminta oleh UU itu tidak mudah. b. terdapat kesulitan dan kekurangcermatan dalam menentukan sebuah Merek untuk diterima atau ditolak pendaftarannya baik yang disebabkan adanya unsur itikat tidak baik dari pemohon, maupun kemungkinan terdapatnya persamaan dengan Merek milik pihak lain. c. belum adanya ukuran atau kriteria yang jelas untuk menentukan apakah subuah Merek yang diajukan pendaftarannya dapat diterima atau ditolak, baik berhubungan dengan persyaratan etikad baik, maupun yang berhubungan dengan persamaan antara Merek yang diajukan pendaftarannya dengan Merek milik pihak lain. d. masih terdapat kelemahan pemberlakuan Sistem Konstitutif, baik dari aspek pengaturan maupun dalam impelentasinya.

\section{Model Pemberlakuan Sistem Konstitutif atau First to File untuk Memberikan Kepastian Hukum yang Adil.}

Tidak dipungkiri bahwa sejak diberlakukannya Sistem Konstitutif dalam pendaftaran Merek, masih banyak Merek-Merek yang tidak didaftarkan oleh

${ }^{20}$ Wawancara kepada bapak Adi Supanto, S.H., Komisi Banding pada Direktorat Merek Direktorat Jenderal Kekayaan Intelektual pada Kementerian Hukum dan Hak Asasi Manusia Republik Indonesia, pada 4 Maret 2016, juga Wawancara kepada DR. Yanto, S.H.,M.H, hakim bersertifikat hakim Niaga dan saat ini Ketua Pengadilan negeri Sleman, 14 Maret 2016. 
pemiliknya, baik yang digunakan untuk Merek barang maupun Merek jasa. Pada umumnya para produsen dan yang memperdagangkan barang, maupun jasa pada awal usahanya tidak menggunakan tanda apapun sebagai Merek, kemudian dalam perkembangan usahanya dengan maksud sebagai tanda atas barang ataupun jasa yang diperdagangkan menggunakan simbul atau tanda yang digunakan sebagai Merek. Namun sayangnya Merek tidak serta merta diikuti dengan pendaftaran, karena yang terpenting bagi pelaku usaha barang ataupun jasa yang diperdagangkan laku dan disukai konsumen. Sebagian kurang mempertimbangkan dari aspek perlindungan hukum atas penggunaan Mereknya, bahkan kemungkinan ditiru oleh pihak lain tidak memperdulikan.

Berdasarkan analisis data dan keterangan yang diperoleh dari observasi di lapangan, pada umumnya faktor yang mempengaruhi pemilik menggunakan Merek tidak mendaftarkan Mereknya, antara lain: pertama, sebagian pihak masih kurang mengetahui dan memahami adanya kewajiban pendaftaran Merek, dan juga fungsi serta manfaat pendaftaran Merek terutama bagi pemilik Merek dan juga bagi masyarakat dalam menentukan pilihan terhadap barang atau jasa yang dibutuhkan. Kedua, tidak adanya sangsi yang tegas bagi pemilik dan pengguna Merek yang tidak terdaftar, tapi justru terdapat ketentuan yang masih memberikan perlindungan bagi pemilik Merek yang tidak terdaftar, antara lain: a. mewajibkan menolak pendaftaran Merek yang sama pada pokoknya atau pada keseluruhannya dengan Merek terkenal pihak lain sekalipun tidak terdaftar; b. adanya ketentuan yang memberikan hak bagi pemilik Merek yang tidak terdaftar untuk mengajukan gugatan pembatalan Merek.

Masih terdapatnya ketentuan yang memberikan perlindungan kepada pemilik Merek yang tidak terdaftar tersebut sebagai pengecualian dari Sistem Konstitutif dalam pendaftaran Merek yang mestinya hanya memberikan hak dan perlindungan kepada pemilik Merek terdaftar saja. Namun dalam pemberlakuan Sistem Konstitutif tersebut masih memberikan pengecualian dengan memberikan perlindungan kepada pemilik Merek yang tidak terdaftar, seperti pada ketentuan penolakan dan pembatalan Merek. 
Dalam ketentuan Pasal 68 ayat (2) ditentukan bahwa Pemilik Merek yang tidak terdaftar dapat mengajukan gugatan pembatalan Merek sebagaimana dimaksud pada ayat (1) setelah mengajukan Permohonan kepada Direktorat Jenderal. ${ }^{21}$ Dalam ketentuan yang memperbolehkan pemilik Merek tidak terdaftar untuk mengajukan gugatan pembatalan Merek tersebut tanpa disertai syarat. Seharusnya disertai syarat misalnya Merek dimaksud termasuk dalam kriteria Merek terkenal, atau setidaknya juga terdapat syarat bahwa pendaftar Merek yang diajukan pembatalan adalah pendaftar yang beretikad tidak baik.

Pemberian pengecualian dalam Sistem Konstitutif dengan masih memberikan perlindungan kepada Merek yang tidak terdaftar, dapat dimanfaatkan oleh pemilik Merek asing yang telah menggunakan Mereknya di Indonesia tidak segera mendaftarkan Mereknya. Pemilik Merek asing memilih menunggu, seandainya Mereknya didaftarkan oleh pengusaha lokal, baru pemilik merek asing melakukan upaya gugatan pembatalan disertai dengan pengajuan pendaftaran mereknya sesuai hak bagi pemilik Merek yang tidak terdaftar untuk dapat mengajukan gugatan pembatalan seperti ketentuan Pasal 68 ayat (2) UU Merek. Hal ini tentunya dapat merugikan dan menimbulkan ketidakadilan bagi pengusaha lokal yang selalu dalam posisi lemah dalam bersaing dengan pengusaha asing.

Pada dasarnya Merek adalah sebagai tanda atau identitas untuk membedakan antara barang atau jasa yang satu dengan barang atau jasa lain yang diperdagangkan. Dengan sebuah Merek, maka suatu barang atau jasa dapat dipribadikan dan berbeda dengan barang atau jasa lainnya. Merek mempunyai fungsi yaitu sebagai alat pembeda antara barang atau jasa yang satu dengan barang atau jasa yang lain, terutama barang atau jasa yang sejenis. Pada umumnya masyarakat dapat mengerti serta dapat membedakannya antara Merek terkenal dan tidak terkenal. Merek mempunyai arti yang sangat penting maka perlu adanya perlindungan terhadap Merek atau hak atas Merek kepada pemegang Merek terdaftar. ${ }^{22}$

\footnotetext{
${ }^{21}$ Lihat Pasal 68 Undang-Undang Nomor 15 Tahun 2001 tentang Merek (Lembaran Negara Republik Indonesia Tahun 2001 Nomor 110 dan Tambahan Lembaran Negara Republik Indonesia Nomor 4131).

${ }^{22}$ Haryono, "Perlindungan Hukum..., Op. Cit., hlm. 240.
} 
Dengan tanda atau identitas tersebut sekaligus sebagai pertanggungjawaban pelaku usaha yang memperdagangkan dan mengedarkan ataupun yang mengusahakan sebuah barang atau jasa, bahwa ia harus bertanggungjawab atas barang atau jasa yang ia perdagangkan atau usahakan. Dalam hal terjadi masalah terhadap barang atau jasa yang diperdagangkan, bahkan kemungkinan mengakibatkan kerugian pihak lain atau konsumen, maka akan mudah mencari siapa pemilik usaha dan yang harus dipertanggungjawabkan atas peredaran barang atau jasa dimaksud.

Bagi masyarakat konsumen akan lebih mudah menentukan pilihan atas barang atau jasa yang dibutuhkan, dengan mengetahui siapa pemilik usaha yang mengedarkan barang atau mengusahakan jasa dimaksud, sekaligus kemungkinan digunakan sebagai pertimbangan kualitas bagi konsumen dalam memilih barang barang dapat ditunjukkan dari Merek yang bersangkutan. ${ }^{23}$ Hal tersebut sesuai dengan fungsi Merek juga dapat sebagai pengenal dan jaminan kualitas atas barang atau jasa yang diberi Merek. ${ }^{24}$

Kualitas barang dan jasa umumnya menjadi salah satu pertimbangan bagi konsumen untuk memilih barang dan jasa yang dibutuhkan. Dari sebuah survei menunjukkan bahwa konsumen memiliki kebutuhan psikologis yang mendasar untuk membeli suatu produk dengan kepastian kualitas. Kepastian kualitas membuat konsumen merasa aman. ${ }^{25}$ Seaiknya perlu ada ketentuan larangan atas peredaran barang atau jasa yang menggunakan Merek yang tidak terdaftar, sehingga diharapkan ketika ada suatu barang atau jasa yang telah diedarkan atau diusahakan dengan menggunakan Merek, maka Merek tersebut harus terdaftar dan apabila ketentuan ini dilanggar diberikan sanksi yang tegas. Ketentuan yang tegas terhadap kewajiban pendaftaran Merek dengan pemberian sanksi ini juga

23 Baca juga Wiratmo Dianggoro, Pembaharuan Undang-Undang Merek dan Dampaknya Bagi Dunia Bisnis, Yayasan Perkembangan Hukum Bisnis, Jakarta ,1997, hlm. 34, bahwa dari sisi produsen, Merek digunakan se-bagai jaminan nilai hasil produksinya, khu-susnya mengenai kualitas kemudian pemakai-nya. Dari sisi konsumen, Merek diperlukan untuk melakukan pilihan barang yang akan dibeli, dikutib dari Haedah Faradz, "Perlindungan Hak Atas Merek", Jurnal Dinamika Hukum Vol. 8 No. 1 Januari 2008, hlm. 97.

${ }^{24}$ Baca Abdulkadir Muhammad, Kajian Hukum Ekomi Hak Kekayaan Intelektual, Citra Aditya, Bandung, 2001, hlm. 120-121. Bahwa fungsi Merek adalah sebagai tanda pengenal untuk membedakan produk perusahaan yang satu dengan produk perusahaan yang lain (product identity), sarana promosi dagang (means of trade promotion), jaminan atas mutu barang atau jasa (quality quarantee), dan penunjukkan asal barang atau jasa yang dihasilkan (source of origin).

${ }^{25}$ Laude Rudita, Hak Kekayaan Intelektual $※$ Perlindungan Konsumen (Sudi tentang Indikasi Geografis dari Perspektif Kepentingan Konsumen), Disertasi, Pascasarjana Universitas Indonesia, Jakarta, 2011, hlm. 76 
memberikan dampak positif bagi penerimaan negara bukan pajak, karena dengan semakin banyaknya Merek yang didaftarkan akan menambah penerimaan negara, disamping ketertiban administrasi di bidang Merek.

Penerapan Sistem Konstitutif dalam UU Merek selama ini hanya sebatas menyangkut kewajiban yang beraspek kepentingan hak keperdataan bagi pendaftar. Perlu dilakukan perubahan dalam penerapan Sistem Konstitutif secara ketat dan konsisten, tidak hanya menyangkut kewajiban yang beraspek keperdataan bagi kepentingan hak pendaftar saja, tetapi juga aspek kepentingan publik. Kewajiban pendaftaran harus disertai sanksi bagi pemilik dan menggunakan Merek yang tidak mendaftarkan Mereknya. Dengan pemberian sanksi bagi pemilik yang menggunakan Merek namun tidak mendaftarkan Mereknya, diharpkan dapat memberikan kepastian hukum yang adil dan dapat menciptakan tertib administrasi Merek bahkan akan menambah pendapatan negara.

Sistem pengaturan pendaftaran Merek dengan Sistem Konstitutif dalam Undang-undang Merek tidak konsisten, karena masih dimungkinkannya pemilik Merek yang tidak terdaftar untuk mengajukan gugatan pembatalan Merek terdaftar, tanpa syarat terkenal. Hal ini mengakibatkan pemberlakuan Sistem Konstitutif dalam pendaftaran Merek se olah-olah tidak bermakna dan hak Merek terdaftar menjadi lemah / tidak kuat dan menimbulkan ketidakpastian hukum.

Pejabat pendaftaran Merek seharusnya menolak permohonan pendaftaran Merek yang sama dengan merek terkenal telah terdaftar lebih dahulu. ${ }^{26}$ Perlindungan Merek melalui sistem pendaftaran mempunyai tujuan, antara lain perlindungan pengusaha pemilik Merek, perlindungan konsumen, perlindungan masyarakat melalui pencegahan dan penanggulangan segala bentuk persaingan curang, keadilan, ketertiban, dan kepastian hukum, sehingga apabila pendaftaran Merek berlawanan dengan tujuan tersebut tentunya perlu dicegah. ${ }^{27}$ Secara hukum positif pengaturan dalam Undang-undang melalui pendataran Sistem Konstitutif

${ }^{26}$ Lihat juga Muhamad Djumhana, dan Djubaedilah, Hak Milik Intelektual (Sejarab, Teori dan Prakteknya di Indonesia), PT. Citra Aditya Bakti, Bandung, 1993, hlm. 128, bahwa Bagi orang yang mendaftarkan Mereknya terdapat suatu kepastian hukum bahwa dialah yang berhak atas Merek itu. Sebaliknya bagi pihak lain yang akan mempergunakan Merek yang sama atas barang atau jasa lainnya yang sejenis oleh kantor Merek akan ditolak pendaftarannya.

${ }^{27}$ Nur Hayati, "Perlindungan hukum pada Merek yang Terdaftar", dalam Ragam Jurnal Pengembangan Humaniora, Vol. 11 No. 3, Desember 2011, hlm. 176. 
juga dapat memberikan kepastian hukum, dengan memberikan hak berdasarkan Undang-undang. Demikian pula dalam praktek implementasinya, pemilik Merek terdaftar mestinya akan memperoleh kepastian hukum dalam hal perlindungan hukumnya. Namun dalam undang-undang masih memungkinkan gugatan pembatalan Merek oleh pemilik Merek yang tidak terdaftar dan dalam kenyataannya masih banyak kasus pembatalan Merek yang sudah terdaftar. Beberapa contoh kasus pembatalan Merek antara lain : Putusan Mahkamah Agung Republik Indonesia pada tingkat Kasasi, dalam perkara Eddy v. Crocodile International PTE.LTD, perkara Joko D. Kusuma Tjiam \&Liong Heng Gip v. HARBY'S Corporation NV, perkara Prada S.A. dahulu dikenal dengan nama PREFEL S.A v. Fahmi Babra, dan dalam perkara INTER IKEA SYSTEM B.V v PT. RATANIA KHATULISTIWA dll.

Dengan pemberlakuan Sistem Pendaftaran Konstitutif yang tidak konsisten ini mempengaruhi pemilik Merek enggan atau tidak mau mendaftarkan Mereknya, karena kalaupun tidak mendaftarkan Mereknya tetap memperoleh perlindungan, bahkan dapat mengajukan pembatalan ketika Mereknya didaftar tanpa hak oleh pihak lain.

Solusinya adalah dengan menerapkan pengaturan pendaftaran Merek dengan Sistem Konstitutif secara ketat dan konsisten, artinya yang memperoleh perlindungan hukum hany diberikan kepada pemilik Merek yang terdaftar sesuai dengan peraturan per undang-undangan yang berlaku, baik berupa hak mengajukan gugatan pembatalan atau mengajukan gugatan ganti rugi secara perdata, maupun upaya hukum secara pidana.

Masih terdapatnya ketentuan yang memberikan perlindungan hukum bagi pemilik Merek yang tidak terdaftar, mempengaruhi keengganan pemilik Merek untuk mau mendaftarkan Mereknya. Pertimbangannya karena kalaupun tidak didaftarkan masih dilindungi bahkan kalau dikemudian hari Mereknya dipakai dan di daftarkan oleh pihak lain, masih dapat melakukan gugatan pembatalan. Ketentuan ini sebenarnya memperlemah makna dari Sistem Konstitutif dalam undang-undang Merek, dan menunjukkan ketidak konsistenan pemberlakuan Sistem Konstitutif yang mengharuskan adanya pendaftaran Merek. Dalam 
kenyataannya terjadi beberapa sengketa pembatalan Merek terdaftar yang menggambarkan ketidakpastian hukum bagi pemilik Merek terdaftar, karena kalaupun dapat diterima pendaftarannya dengan adanya gugatan pembatalan akhirnya dibatalkan.

Terdapat ketidak cermatan dalam menentukan sebuah Merek dapat diterima atau ditolak pendaftarannya, beberapa Merek yang sebenarnya secara jelas mudah diketahui terdapat kesamaan dengan Merek terkenal yang sudah dimiliki oleh pihak lain, tetap saja diterima pendaftarannya, dan akhirnya timbul sengketa dan dibatalkan. ${ }^{28}$ Seharusnya dalam pendaftaran Merek, sebuah Merek dapat diterima pendaftarannya dilakukan dengan lebih cermat dan hati-hati, kalau sebuah Merek sudah jelas dimiliki oleh pihak lain apalagi mengandung unsur terkenal, maka sesuai Pasal 6 ayat (1) Undang-undang Merek harus ditolak, sehingga tidak menimbulkan sengketa dikemudian hari.

Dalam menentukan apakah sebuah Merek yang diajukan pendaftaran itu sama dengan Merek milik pihak lain atau tidak sama, perlu dibangun sebuah sistem yang dapat memudahkan dan memberi kepastian untuk menenentukan sebuah Merek dapat diterima pendaftarannya atau di tolak. Bila perlu melalui sistem elektronik atau on line yang dapat diakses siapa saja terutama pihak-pihak yang berkepentingan, seperti halnya pengesahan bahan hukum yang sudah dilakukan secara elektronik dengan Sistem Administrasi Badan Hukum (SABH) di Kementerian Hukum dan Hak Asasi Manusia, termasuk dalam melakukan pengecekan nama sebuah badan hukum seperti Perseroan Terbatas (PT) yang akan didirikan. Misalnya bagi pihak yang akan mendirikan PT dapat mengecek nama terlebih dahulu secara elektronik atau online, apabila terdapat nama yang sama maka sistem akan memberitahukan. Demikian pula dalam pendaftaran Merek, bagi pemohon yang akan mendaftarkan Merek dapat mengecek Mereknya terlebih dahulu apakah sama dengan Merek yang sudah terdaftar dengan Merek pihak lain atau tidak, apabila ada kesamaan sistem akan menolak, sedangkan apabila tidak

${ }^{28}$ Hasil Wawancara kepada Bapak Suharyanto, S.H, Ka.Sub.Dit Pelayanan Hukum Umum yang juga membidangi HAKI, pada Kantor Wilayah Kementerian Hukum dan Hak Asasi Manusia Daerah Istimewa Yogyakarta, pada 14 Maret 2016, yang membenarkan pernyataan bahwa masih terjadi penerimaan pendaftaran Merek yang secara jelas nampak sama dengan Merek pihak lain bahkan sudah terdaftar yang semestinya harus ditolak. 
ada maka dapat diproses pendaftarannya lebih lanjut yang dapat dilakukan melalui sistem elektronik atau on line. Dengan pendaftaran secara elektronik atau sistem on line maka akan mempermudah dan mempercepat sekaligus lebih efisien dalam pendaftaran Merek, dan sekaligus akan meningkatkan penerimaan negara.

\section{Penutup}

Berdasarkan uraian pembahasan hasil penelitian tersebut, maka dapat disusun beberapa kesimpulan sebagai berikut, pertama, landasan filosofis pergeseran dalam pengaturan hak Merek dari Sistem Deklaratif (First to Use) dalam UU Merek Tahun 1961 ke dalam Sistem Konstitutif (First to File) dalam UU Merek 1992 hingga diganti dengan UU Merek Tahun 2001, adalah demi tercapainya tujuan hukum, yaitu untuk menjamin kepastian hukum dan rasa keadilan dalam perlindungan hak bagi pemilik merek terdaftar.

Kedua, terjadinya beberapa pendaftaran Merek yang sama dengan Merek milik pihak lain bahkan mempunyai reputasi terkenal, pada umumnya dilandasi adanya niat itikad tidak baik pendaftar yang mengutamakan kepentingan sendiri demi keutungan sendiri dengan mendompleng ketenaran Merek milik pihak lain dan mengabaikan kepentingan pemilik Merek yang sebenarnya. Adanya kesulitan dan ketidakcermatan pejabat pendaftar Merek dalam menentukan apakah pemohon beritikad baik atau tidak dan Merek yang diajukan pendaftarannya mengandung persamaan atau tidak dengan Merek milik pihak lain.

Ketiga, model pengaturan pendaftaran Merek untuk memberikan kepastian hukum yang adil, yaitu memberlakukan Sistem Konstitutif atau "First to File" secara ketat dan konsisten. Hak dan perlindungan Merek hanya diberikan kepada pemilik Merek terdaftar, dan gugatan pembatalan hanya dapat dilakukan oleh pemilik Merek Terdaftar. Di samping itu, penerapan Sistem Konstitutif tidak hanya menyangkut kewajiban yang beraspek hak keperdataan bagi kepentingan pendaftar saja, tetapi juga menyangkut aspek kepentingan publik, dengan memberikan sanksi bagi yang menggunakan Merek namun tidak mendaftarkan Mereknya.

Adapun berdasarkan uraian pembahasan hasil penelitian tersebut, penulis menyarankan sebagai berikut; pertama, apabila dalam permohonan pendaftaran 
Merek terdapat unsur pemohon yang beritikad tidak baik, atau Merek yang diajukan pendaftarannya mengandung persamaan baik pada pokoknya atau sama pada keseluruhannya dengan Merek terdaftar pihak lain, atau setidaknya sama dengan Merek terkenal milik pihak lain, seharusnya tidak dilakukan pendaftaran atau ditolak pendaftarannya, agar tidak mudah terjadi gugatan pembatalan Merek akibat dari pendaftaran Merek yang dilakukan oleh pihak lain. Kedua, untuk memudahkan dan kelancaran dalam menentukan apakah sebuah Merek yang diajukan pendaftaran sama dengan Merek pihak lain yang sudah terdaftar lebih dahulu, atau dengan Merek yang sudah terkenal, maka data base secara elektronik perlu lebih disempurnakan. Masyarakat terutama yang berkepentingan dapat mengakses data Merek lebih mudah, dan dari awal sudah dapat mengecek Merek yang diajukan pendaftarannya, seperti halnya cek nama pada pendirian badan hukum seperti PT melalui Sistem Administrasi Badan hukum (SABH). Ketiga, perlu menerapkan kententuan yang memberlakukan Sistem Konstitutif dalam pendaftaran Merek secara ketat dan konsisten, dengan menghilangkan ketentuan yang memungkinkan pemilik Merek tidak terdaftar untuk mengajukan gugatan pembatalan Merek terdaftar, karena hal ini berakibat memperlemah Sistem Konstitutif, dan menimbulkan ketidak pastian hukum. Bila perlu memberikan sanksi bagi pemilik yang tidak mendaftarkan Mereknya. Keempat, perlu dibangun sistem yang lebih mempermudah pendaftaran Merek, dengan sistem on line atau elektronik, yang dapat dilakukan secara mudah, cepat dan efisien. Dengan memberikan kemudahan kepada pendaftar Merek melalui sistem elektronik ini akan memberikan daya tarik dan membangun kesadaran bagi pemilik Merek untuk mendaftarkan Mereknya, jumlah pendaftar akan bertambah banyak, dengan sendirinya akan menciptakan ketertiban dibidang administrasi pendaftaran Merek, sekaligus akan menambah pendapatan negara melalui biaya pendaftaran.

\section{Daftar Pustaka}

\section{Buku}

Asian Law Group Pty Ltd, Hak Kekayaan Intelektual Suatu Pengantar, Cet. 5, Alumni, Bandung, 2005.

Dianggoro, Wiratmo, Pembaharuan Undang-Undang Merek dan Dampaknya Bagi Dunia Bisnis, Yayasan Perkembangan Hukum Bisnis, Jakarta, 1997. 
Djumhana, Muhamad dan Djubaedillah, Hak Milik Intelektual, Sejarah, Teori, dan Praktiknya di Indonesia, PT Citra Aditya Bakti, Bandung, 2014.

, Hak Milik Intelektual (Sejarah, Teori dan Prakteknya di Indonesia), PT. Citra Aditya Bakti, Bandung, 1993.

Firmansyah, Hery, Perlindungan Hukum Terhadap Merek, Panduan Memahami Dasar Hukum Penggunaan Dan Perlindungan Merek, Pustaka Yustisia, Yogyakarta, 2011.

Gautama, Sudargo, dan Rizawanto Winata, Undang-Undang Merek Baru Tahun 2001, Bandung, PT. Citra Aditya Bakti, 2002.

Gautama, Sudargo, Hukum Merek Indonesia, PT. Citra Aditya Bakti, Bandung, 1989.

Ibrahim, Johnny, Teori \& Metode Penelitian Hukum Normatif, cet. pertama, Bayumedia Publishing, Malang, 2005.

Moleong, Lexy J., Metodologi Penelitian Kualitatif, Bandung, PT. Remaja Rosdakarya, 1989.

Muhammad, Abdulkadir, Kajian Hukum Ekomi Hak Kekayaan Intelektual, Citra Aditya, Bandung, 2001.

Projomardojo, Hartono, "UU Merek 1961 dan Permasalahan-nya Dewasa Ini", Hukum Atas Merek, Badan Pembinaan Hukum Nasional, Bina Cipta, Jakarta, 1978,.

Purwaningsih, Endang, Perkembangan Hukum Intellectual Property Rights Kajian Hukum Terhadap Hak atas Kekayaan Intelektual dan Kajian Komparatif Hukum Paten, Ghalia Indonesia, Bogor, 2005.

Saidin, OKH., Aspek Hukum Hak Kekayaan Intelektual (Intellectual Property Rights, PT Raja Grafindo Persada, Jakarta, 2003.

Sumida, Yoshiro dan Insan Budi Maulana, Perlindungan Bisnis Merek IndonesiaJepang, Pustaka Sinar Harapan, Jakarta, 1994.

Suratman, dan Philips Dillah, Metode Penelitian Hukum, Alfabeta, Bandung, 2012.

Vredenbregt, J., Metode dan Teknik Penelitian Masyarakat, PT Gramedia, Jakarta, 1978.

Waluyo, Bambang, Penelitian Hukum Dalam Praktek, Sinar Grafika, Jakarta, 1991.

\section{Hasil Penelitian}

Laude Rudita, 2011, “Hak Kekayaan Intelektual \& Perlindungan Konsumen (Sudi Tentang Indikasi Geografis Dari Perspektif Kepentingan Konsumen)", Disertasi, Jakarta, Pascasarjana Universitas Indonesia.

\section{Artikel Jurnal}

Faradz, Haedah, "Perlindungan Hak Atas Merek", Jurnal Dinamika Hukum Vol. 8 No. 1 Januari 2008. 
Haryono, "Perlindungan Hukum Terhadap Merk Terdaftar", Jurnal Ilmiah CIVIS, Volume II, No 1, Januari 2012.

Hayati, Nur, "Perlindungan hukum pada Merek yang Terdaftar", dalam Ragam Jurnal Pengembangan Humaniora, Vol. 11 No. 3, Desember 2011.

Maulana, Insan Budi, "Merek Terkenal Menurut TRIPs Agreement dan Penerapan dalam Sistem Merek Indonesia", Jurnal Hukum Ius Quia Iustum, Nomor 13 Vol. 7, April 2000.

\section{Sumber Lain}

Wawancara kepada bapak Adi Supanto, S.H., Komisi Banding pada Direktorat Merek Direktorat Jenderal Kekayaan Intelektual pada Kementerian Hukum dan Hak Asasi Manusia Republik Indonesia, pada 4 Maret 2016.

Wawancara kepada DR. Yanto, S.H.,M.H., hakim bersertifikat hakim Niaga dan saat ini Ketua Pengadilan negeri Sleman, 14 Maret 2016.

Wawancara kepada Bapak Suharyanto, S.H, Ka. Sub.Dit Pelayanan Hukum Umum yang juga membidangi HAKI, pada Kantor Wilayah Kementerian Hukum dan Hak Asasi Manusia Daerah Istimewa Yogyakarta, pada 14 Maret 2016.

\section{Peraturan Perundang-Undangan}

Undang-Undang Nomor 19 Tahun 1992 Tentang Merek (Lembaran Negara Republik Indonesia Tahun 1992 Nomor 81, Tambahan Lembaran Negara Republik Indonesia Nomor 3490).

Undang-Undang Nomor 15 Tahun 2001 Tentang Merek (Lembaran Negara Republik Indonesia Tahun 2001 Nomor 110, Tambahan Lembaran Negara Republik Indonesia Nomor 4131). 